УДК 336.7

DOI: https://doi.org/10.26642/jen-2019-3(89)-215-221

А.В. Буряк, к.е.н., доц.

Я.М. Кривич, к.е.н., доц.

К.В. Сердюк, магістр

Сумський державний університет

\title{
Економічні очікування агентів фінансового сектору в контексті комунікаційної політики центрального банку
}

\begin{abstract}
Статтю підготовлено в межах виконання науково-дослідної роботи молодих науковців на тему «Економіко-математичне моделювання механізму відновлення суспільної довіри до фінансового сектору: запорука економічної безпеки України» (номер держ. реєстрації 0117U003924)
\end{abstract}

Очінка економічних очікувань агентів фінансового сектору має неоціненний внесок до розвитку грошово-кредитної системи кожної країни. Важливість вивчення настроїв споживачів, домогосподарств та бізнесу відображена в сучасних напрямах діяльності центральних банків. Саме за допомогою комунікаційної політики центральні банки світу та України зокрема мають можливість проаналізувати поточний стан на фінансовому ринку та майбутні очікування стосовно ряду питань. Збір інформації $\epsilon$ важливою частиною управління економічними очікуваннями агентів фінансового сектору. Для цього й використовуються різного роду канали та інструменти комунікації, що постійно вдосконалюються, щзоб якомога ближче бути 3 агентами фінансового сектору. Складність дослідження економічних очікувань пояснюється їх залежністю від багатьох факторів, одним з яких є здатність респондентів оцінити зміни в економіці та надати відповіді, щео не будуть залежати від їх імпульсивності та неупередженості думок, а навпаки матимуть економічне підгрунтя для подальшого аналізу всіх відповідей у сукупності. Прозорість і комунікація центрального банку відіграють важливу роль, насамперед, при управлінні інфляційними очікуваннями, оскільки вони можуть зменшити асиметричну інформацію між иентральним банком $i$ громадськістю. Оскільки економічні агенти використовують всю наявну інформаџію для формування своїх очікувань, а отже, комунікаціі центтрального банку відіграють ключову роль у прочесі формування циих очікувань.

Ключові слова: комунікаційна політика; економічні очікування; агенти фінансового сектору; інфляційні очікування; індекс споживчих настроӥв; індекс ділових очікувань.

Актуальність теми. Результати сучасних досліджень свідчать, що фінансові ринки та інфляційні очікування зокрема реагують на оголошення та сигналізацію монетарної політики. Проте повною мірою існуюча література не дає прямих емпіричних даних про взаємозв'язок між довірою до центральних банків та економічними очікуваннями, тим паче між очікуваннями та механізмом комунікації центральних банків. Не є виключенням, що практика центральних банків світу з цього питання є різною: $\epsilon$ гарні приклади комунікаційної політики, $є$ й невдалі. Стосовно України, то наразі ситуація в країні з результатом комунікацій центрального банку покращилася та почала давати позитивні наслідки у питанні вивчення очікувань економічних агентів фінансового сектору.

Аналіз останніх досліджень та публікації, на які спирається автор. Питання комунікаційної політики розглядають як у вітчизняній, так і зарубіжній літературі. Проте комунікаційну політику на прикладі Національного банку України почали вивчати декілька років тому. Це питання у своїх роботах розглядають такі науковці: М.Репко, Т.Щербина, О.Уткіна, В.Піддубна, А.Сомик, Н.Жмурко, Н.Маслова, Л.Сегеда, В.Міщенко та інші.

У закордонній літературі взаємозв’язку економічних очікувань та комунікаційної політики присвячено набагато більше досліджень, ніж в Україні. Зокрема, варто згадати: Carola Binder, Nikolaos Kokonas \& Michalis Rousakis, Leif Brubakk \& Tommy Sveen, Olivier Coibion, Yuriy Gorodnichenko, Saten Kumar та інші. Однак досі не досліджено на достатньому рівні механізм вивчення економічних очікувань у контексті впровадження комунікаційної політики центральним банком і тому досить часто комунікації центрального банку не мають бажаного позитивного ефекту при прогнозуванні макроекономічних показників, що базуються саме на очікуваннях агентів фінансового сектору.

Постановка завдання. Метою статті є формування теоретичного та методичного підгрунтя дослідження економічних очікувань, вивчення генезу економічних очікувань, обгрунтування взаємозв'язку економічних очікувань та безпосередньо комунікаційної політики Національного банку України, а також аналіз поточного стану інфляційних очікувань агентів фінансового сектору.

(C) А.В. Буряк, Я.М. Кривич, К.В. Сердюк, 2019 
Викладення основного матеріалу. Протягом останніх трьох десятиліть більшість центральних банків усвідомила, що ефективність політики в основному залежить від їх здатності впливати на очікування агентів фінансового сектору. Однією з основних причин важливості моніторингу очікувань широкої громадськості $\epsilon$ те, що такі очікування містять важливу інформацію для центрального банку у досягненні своїх цілей та зобов'язань (наприклад, основною метою ЄЦБ є підтримка цінової стабільності, у інших країнах - підтримка інфляції). Таким чином, вирівнювання очікувань громадськості з очікуваннями центральних банків $є$ корисним.

Вважається, що очікування впливають на економіку та іiі розвиток, i, навпаки, можна обгрунтовано припустити, що сам економічний розвиток впливає на очікування. Стандартна методологія моделювання очікувань полягає в прийнятті раціональних очікувань, що насправді відображають рівновагу в цих двосторонніх відносинах. Економісти давно визнали, що очікування відіграють важливу роль у прийнятті економічних рішень і є критичною особливістю макроекономічних моделей [1].

В цілому економічні очікування можна трактувати як наміри та прогнози агентів фінансового сектору стосовно ряду питань, що є першочерговими для економіки. Варто виокремити, що ці очікування можуть бути оптимістичними або песимістичними по відношенню до того, яка ситуація склалася на грошовому ринку або від прогнозних оцінок експертів. У результаті вивчення теоретичного матеріалу щодо сутності поняття «комунікаційної політики», то найчастіше ії розглядають як мету грошово-кредитної політики та систему дій, спрямованих на підвищення рівня обізнаності агентів щодо стану та перспектив розвитку монетарної політики і формування позитивного іміджу влади. Також панує думка, що комунікаційна політика важлива для центральних банків для забезпечення стабільності розвитку держави та керування очікуваннями агентів фінансового сектору, щоб привести їх до загального вектору грошово-кредитної політики.

Важливість комунікаційних стратегій для управління економічними очікуваннями було виявлено ще задовго до того, як центральні банки почали активно використовувати інструменти комунікації. Ще 3 початку 1990-х років центральні банки стають все більш відкритими в обговоренні своїх дій, цілей і поглядів на економіку. Ця зміна мотивувалася ідеєю про те, що чітка комунікація може допомогти зменшити фінансову та економічну нестабільність у відповідь на рішення центральних банків, а також збільшити набір інструментів монетарної політики.

Нові комунікаційні стратегії, впроваджені центральними банками 3 кінця 20 століття, значною мірою були успішними в закріпленні довгострокових інфляційних очікувань фінансових ринків у розвинутих країнах. Опис поглядів політиків на економіку та їх очікування щодо майбутніх політичних рішень через політичні заяви, виступи та прес-брифінги після прес-конференції допомогли зменшити волатильність фінансового ринку.

Систематичний економічний аналіз, в якому очікування відіграють головну роль, був опублікований в 1802 році, автором якого був Генрі Торнтон та у 1887 році сформульована структура економічних очікувань Емілем Чейссоном [1]. Раціональні очікування надалі з'явилися в роботі Роберта Е. Лукаса молодшого і Томаса Дж. Сарджент на початку 1970-х років. Сьогодні обмежена раціональність або адаптивне вивчення, що включає механізм навчання в економічній моделі переважають у теоретичному аналізі [2]. Емпіричні дослідження підтверджують, що очікування економічних агентів $є$ упередженими незалежно від територіальної сфери дослідження. Такої думки додержується ряд науковців. Насамперед, Forsells [3], Dias [4], Mitchell [5] та інші.

У літературі також згадуються епідеміологічні очікування Керолла. Науковець стверджує, що споживачі формують свої очікування, враховуючи професійні прогнози, поширені засобами масової інформації. Вони роблять це недосконало, оскільки їм потрібен час для поглинання економічного змісту новин, тому економічні умови потребують певного часу [6].

Процес формування очікувань аналогічний передачі захворювання, яке потребує контакту з загальним джерелом інфекції в популяції. Таким джерелом інфекції для споживчих інфляційних очікувань є ЗМІ. Новина поступово поширюється серед економічних агентів. Інші дослідники, наприклад, як Lama, шукають можливе розширення оригінальних висновків Керролла і вивчають, чи обсяг і зміст медіасигналу можуть впливати на точність прогнозу споживачів [7].

Під час дослідження очікувань економічних агентів традиційно розрізняють корпоративний сектор (бізнес), домогосподарства (споживачі) та інвесторів, які визначають рівень витрат та споживання в економіці залежно від рівня їх впевненості. Відтак рівень впевненості та настрої економічних агентів детермінує їх майбутню поведінку, в тому числі і у фінансовому секторі.

В економіці очікування населення та бізнесу стосуються їх прогнозів або думок, якими вони керуються при прийнятті рішення щодо майбутніх цін, продажів, доходів, податків та інших ключових економічних показників. Важливість цих очікувань обумовлена їх істотним впливом на поточний вибір, а отже, і на загальний рівень економічної активності, оскільки очікування про майбутнє, або навіть теперішнє у цьому питанні відомо лише з невизначеністю. Оскільки більшість економічних рішень, які приймаються споживачами та підприємствами, залежить від їх очікувань щодо майбутніх подій або 
поведінки інших агентів, то це також має важливе значення для розробки та проведення політики будьякої країни [1].

Інфляційні очікування є важливою складовою визначення короткострокової динаміки інфляції, тобто це своєрідний показник найближчого в часі цінового тиску. Якщо ними не управляти, то вони можуть стати самодостатніми і це призведе до значних втрат в економіці. У той час довгострокові інфляційні очікування стають показником довіри економічних агентів до центрального банку. Оскільки довгостроковою метою центральних банків $є$ управління очікуваннями, а в деяких країнах банки мають набагато більш цільову мету «закріпити» свої інфляційні очікування, що є похідними від встановлення довіри, то важливим є правильна оцінка та аналіз цих очікувань. Тоді виникає необхідність проведення комунікаційної політики, яка б допомогла виокремити фактори, що призводять до погіршення очікувань економічних суб'єктів, з метою усунення перешкод до отримання інформації або ж впровадження нових каналів для спілкування центрального банку з цільовою аудиторією.

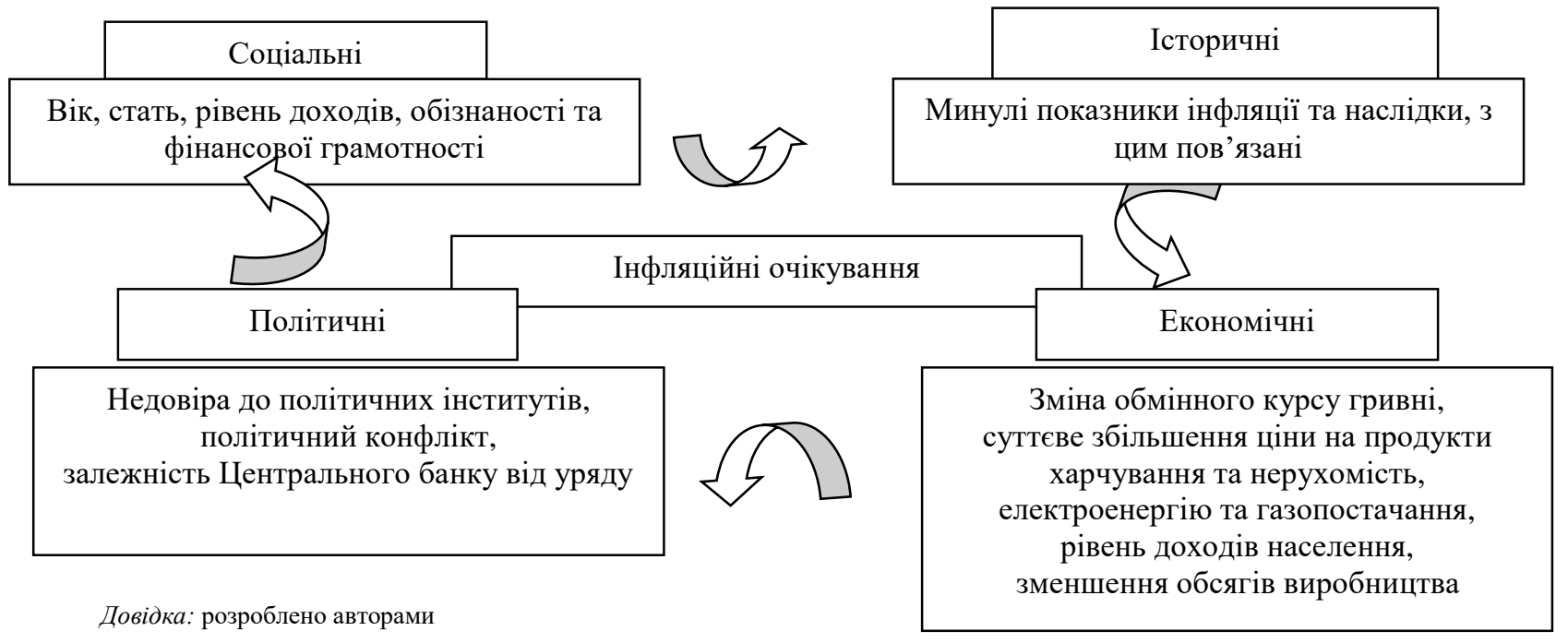

\section{Рис. 1. Система факторів, щ⿻о впливають на інфляційні очікування респондентів}

Очікування в економіці мають гетерогенний характер та показують, якою мірою вони відрізняються від рівня цін цільового орієнтиру по інфляції, а отже, відображаються на довірі до грошово-кредитної політики. Коли ці відхилення невеликі, симетричні та знаходяться близько з цільовим орієнтиром, набагато простіше змінити ситуацію: досить лише збільшити часовий горизонт аналізу. Однак у разі великих економічних шоків відхилення може бути настільки велике, що може обумовити втрату довіри до грошово-кредитної політики. На рисунку 1 представлена узагальнена система чинників, що впливають на інфляційні очікування респондентів.

В цілому за допомогою комунікацій центральний банк має можливість оцінити поточні очікування економічних агентів фінансового сектору та розробити прогнозний план на майбутнє. Залежно від цього очікування можна поділити на дві категорії:

очікування, які сприяють успішному розвитку. Тобто вони будуть змінюватися залежно від ситуації. У деяких випадках може бути краще, якщо люди очікують дуже мало. Наприклад, якщо очікування у цій країні є скромними, координацію навколо ініціатив з розвитку часто буде легше досягти. Якщо населення не очікує значного розвитку за короткий проміжок часу, перешкоди, які виникають, можуть бути пропущені з меншим невдоволенням;

очікування громадян, що бажають негайного розвитку, та їхні наміри не збігаються з поточною ситуацією. У таких випадках громадяни швидко втрачають терпіння і відмовляться підтримувати ініціативи розвитку, а це означає, що в кінцевому підсумку центральні банки не зможуть підтримати довіру та впливати на очікування [8].

Аналізуючи інфляційні очікування, варто наголосити на тому, що центральні банки мають багато комунікувати, щоб досягти бажаного результату. Опитування, анкетування, відкриті прес-конференції застосовуються центральними банками для підвищення своєї прозорості та для вивчення поточної ситуації на ринку. Для того щоб мати позитивний ефект від комунікацій з цільовою аудиторію,центральні банки мають розкривати деякі аспекти своєї політики. Наприклад, такими аспектами є:

- розкриття своєї стратегії та висвітлення основних завдань;

- оцінка інфляційного середовища в країні та висвітлення основних економічних трендів, що $\epsilon$ пріоритетними для країни; 
- висвітлення кількісних показників (пояснення змін облікової ставки, курсу валют та інших основних факторів) для підвищення грамотності населення;

- наміри щодо майбутніх дій у ситуації, що склалася.

У той час коли центральні банки намагаються керувати економічними очікуваннями створюються різного роду макроекономічні моделі, що спираються на кілька різних припущеннь про те, як люди формують очікування. Таким чином, можна виокремити три групи очікувань залежно від економічних умов, що склалися:

- адаптивні очікування, що залежать тільки від минулих спостережень цієї змінної. Більшість таких моделей було розроблено у 1960-х і 1970-х роках;

- раціональні, або модельно-узгоджені, очікування були ідентичні прогнозам макроекономічної моделі, в якій використовуються очікування. Це припущення було використано в багатьох макроекономічних моделях, розроблених за останні п’ятнадцять років, і є одним з варіантів формування очікувань, що використовуються в Сполучених Штатах Америки;

- очікування VAR, що ідентичні прогнозам моделі з невеликою векторною авторегресією, яка містить рівняння для кількох ключових економічних заходів.

Сама ж макроекономічна модель $є$ системою рівнянь, що узагальнюють взаємодію таких економічних змінних, як валовий внутрішній продукт, інфляція та процентні ставки. Залежно від виду економічних очікувань у світі користуються різними моделями. Ці моделі можна згрупувати за такими категоріями:

1) традиційні структурні моделі, що зазвичай базуються на кейнсіанській парадигмі, що характеризується млявою корекцією цін. Ці моделі, як правило, припускають, що очікування $\epsilon$ адаптивними, але враховують їх у загальну динамічну структуру конкретних рівнянь таким чином, що внесок очікувань не ідентифікується;

2) структурні моделі раціональних очікувань, що містять очікування, які узгоджуються зі структурою моделі;

3) рівноважні моделі бізнес-циклів припускають, що ринки праці та товарів завжди перебувають у рівновазі, і що очікування є раціональними. Усі рівняння засновані на припущеннях, що домогосподарства максимізують власне добробут і фірми максимізують прибуток;

4) моделі векторної авторегресії (VAR) використовують невелику кількість оцінених рівнянь для узагальнення динамічної поведінки всієї економіки [10].

Аналізуючи іноземні джерела інформації, можна простежити таку тенденцію: використовується велика кількість моделей щодо того, як розраховуються та вимірюються економічні очікування, насамперед, які стосуються інфляційних очікувань або ж зміни процентної ставки. Деякі автори використовують виключно модель прогнозування очікувань VAR [10]; Leif Brubakk and Tommy Sveen[11] займалися вивченням очікувань домогосподарств. Вони припускали, що існує велика кількість домогосподарств і фірм з однаковими перевагами і технологіями, що полегшило створення моделі. Christelis D., Georgarakos D., Jappelli T., and van Rooij [13] також займалися дослідженням економічних очікувань голландських домогосподарств. У свою чергу Nikolaos Kokonas, Michalis Rousakis [12] орієнтується на лінійні, часові інваріанти, рівноваги раціональних очікувань. Вони дотримуються припущень, що агенти не мають приватної інформації про майбутній стан економіки, тому вони повинні покладатися виключно на комунікацію центрального банку.

Дослідження споживчих (домогосподарств) та ділових настроїв (бізнесу) в Україні проводить дослідницька компанія GfK Ukraine, Національний банк України, Інститут економічних досліджень та політичних консультацій.

В Україні дослідженням економічних очікувань бізнесу займається саме Національний банк, який щоквартально проводить опитування щодо цього питання. У сукупності всі отримані відповіді важливі для розробки монетарної політики, для якої важлива оперативна та різноманітна інформація, яка не завжди складається відділом статистики. Важливість проведення опитувань полягає в тому, що таким своєрідним чином центральний банк підтримує зв'язок з реальним сектором економіки [14].

Дослідження споживчих настроїв проводить дослідницька компанія GfK Ukraine - надійне джерело достовірної інформації стосовно споживчих очікувань. Індекс споживчих настроїв в Україні визначають на підставі вибіркового обстеження домашніх господарств країни, за міжнародною методикою, яка подібна до методики обчислення Мічиганського індексу споживчих настроїв. Значення індексу споживчих настроїв обчислюють таким способом: від частки позитивних відповідей віднімають частку негативних і до цієї різниці додають 100, для уникнення появи від'ємних значень. Сам індекс споживчих настроїв вираховують методом середнього арифметичного п’яти індексів, що оцінюється компанією [14].

Метою дослідження є визначення тенденцій у споживчих настроях домашніх господарств, їх роль у розвитку споживчого ринку на основі результатів соціологічних опитувань для того, щоб мати можливість обгрунтувати пропозиції щодо збереження довіри в країні.

На рисунку 2 представлено динаміку споживчих настроїв домашніх господарств України. Під час дослідження було опитано 1000 осіб віком від 16 років, до квітня 2014 року вибірка дослідження складала 
1000 осіб віком від 15 років. Вибірка репрезентативна за статтю та віком, враховує міське та сільське населення й величину населеного пункту. У зв'язку з політичними подіями з квітня 2014 року в дослідженнях споживчих очікувань було вилучено Автономну Республіку Крим, а у Донецькій та Луганській областях опитування проводилися тільки на територіях, що контролюються Україною.

Аналізуючи рисунок 2, слід зауважити спадаючий тренд, починаючи з 2013 року. 3 пікового значення 2013 року 86 \% економічні очікування домогосподарств України у 2018 році становлять 57,5 \%, що відображає критичне ставлення населення до поточної економічної ситуації в країні, їх впевненість в економіці України з кожним роком падає. Негативно на настрої споживачів за останній рік вплинув ряд факторів, наприклад, різке підвищення ціни на газ та на решту житлово-комунальних послуг, заборгованість по заробітній платі, при одночасному зростанні інфляції та девальвації гривні.

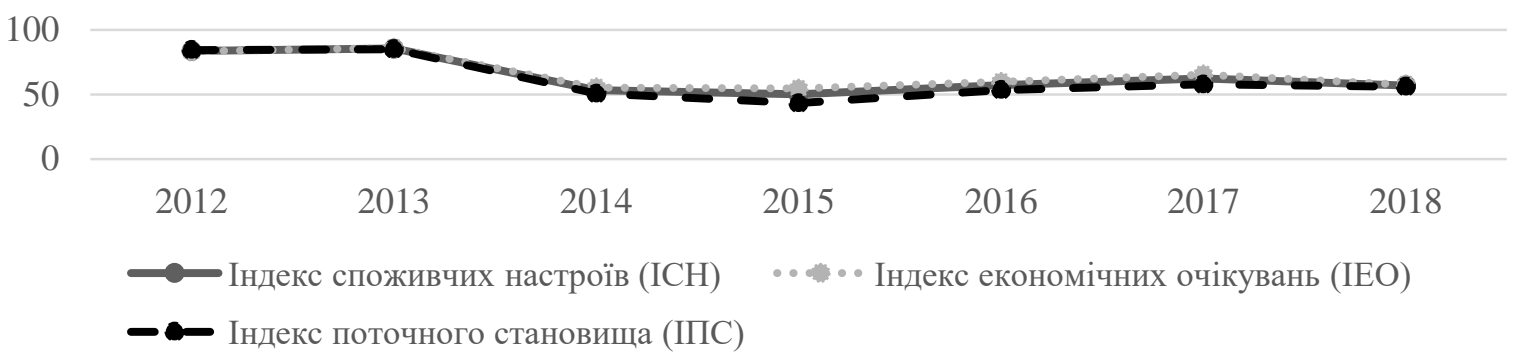

Довідка: складено авторами на підставі [14]

Рис. 2. Динаміка індексу споживчих настроїв в Україні станом на листопад 2012-2018 роки

У зв’язку з такою ситуацією формується негативна тенденція для індексу споживчих настроїв, який 3 83,7 \% у 2013 році зменшився до 56,9 \% у 2018. Індекс відображає споживчу впевненість українців та той факт, що споживачі в Україні останнім часом стали все менше довіряти уряду та Національному банку України, тобто можна констатувати песимістичні настрої споживачів в Україні.

Перед тим як перейти до аналізу ділових очікувань підприємств (бізнесу) в Україні, слід зауважити, що ділові очікування є суб’єктивною оцінкою бізнесу перспектив своєї ділової активності. Індекс формується на основі результатів опитувань підприємств щодо перспектив їх розвитку в наступні 12 місяців, є випереджаючим індикатором щодо розвитку економіки.

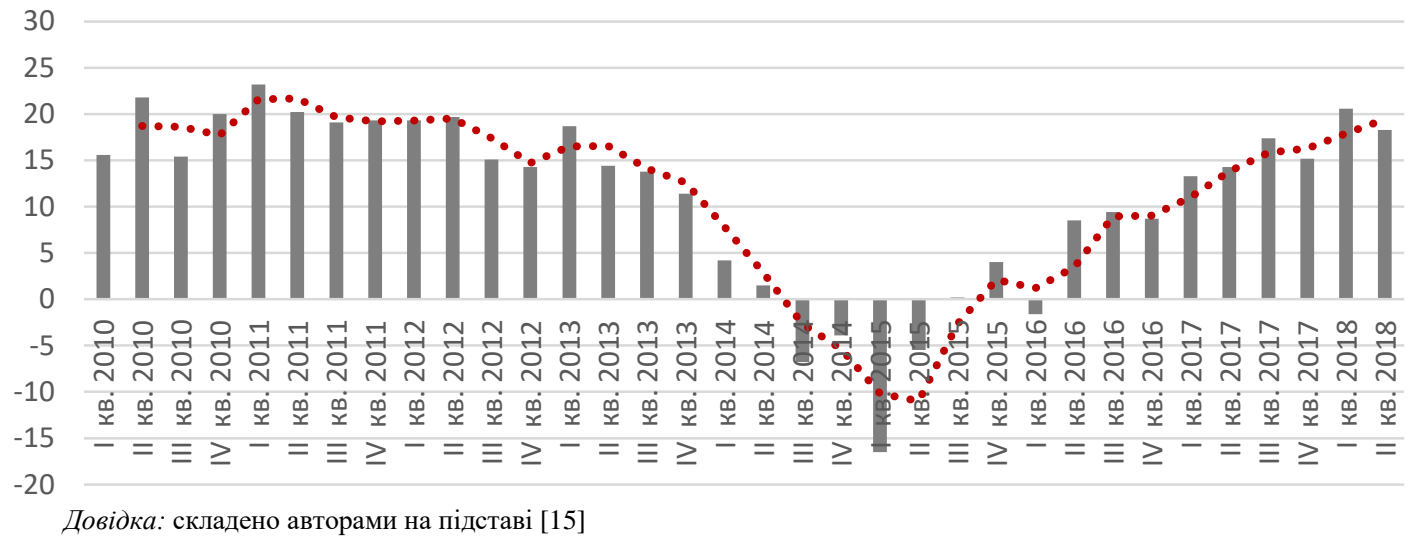

Рис. 3. Динаміка індексу ділових очікувань підприємств за 2013-2018 роки

Під час прийняття рішень на індекс ділових очікувань орієнтуються інвестори - на фінансових ринках, підприємці - під час планування своєї діяльності та органи державної влади, які ухвалюють рішення 3 економічної політики. В цілому індекс ділових очікувань за третій квартал 2018 року становить 117,2 \%, а найменший показник був зареєстрований у 2014 році і становив 96,1 \% (рис. 3), а пік негативних економічних настроїв бізнесу спостерігається з третього кварталу 2014 року по третій квартал 2015 року. 3 березня 2014 року вперше за весь аналізований період було зафіксовано різке зменшення всіх показників ділової активності підприємств України. Підприємства не в змозі були збільшувати своє виробництво, найбільше на це вплинула нестабільна політична ситуація, значні коливання курсу гривні щодо інших валют і занадто високі ціни на енергоносії, сировину та матеріали.

У свою чергу, це призвело до скорочення інвестицій, зменшення обсягів реалізації виробленої продукції і кількості працівників. За перший квартал 2015 року ситуація стала ще гіршою, раніше перелічені фактори стали ще більш вирішальними для підприємств, що посилило спад економічних очікувань на 12,6 \%, порівняно з кінцем 2014 року. До кінця 2015 року ситуація майже стабілізувалася, індекс ділових очкувань мав позитивне значення, проте на початок 2016 року знову відбулося погіршення оцінок респондентів за всіма основними напрямами економічної активності підприємств. Особливо це 
було відчутно на фоні торговельних і транзитних обмежень із боку Російської Федерації і значного коливання курсу гривні у лютому 2016 року та загальної нестабільної політичної ситуації в Україні. Надалі респонденти зберігають оптимістичні очікування щодо макроекономічної ситуації в Україні та розвитку своїх підприємств в цілому.

Висновок. Отже, у статті проаналізовано сутність економічних очікувань та комунікаційної політики центрального банку, досліджено генезис вивчення економічних очікувань, та прослідковано взаємозв'язок інфляційних очікувань та комунікаційної політики центрального банку.

Механізм впливу економічних очікувань на комунікаційну політику центральних банків почали розглядати 3 того часу, коли почалися перші спроби введення інфляційного таргетування в країнах. Саме тоді центральні банки зрозуміли необхідність вивчення економічних настроїв населення, бізнесу та експертів. Очевидний успіх мали ті центральні банки, які змогли правильно трактувати економічні очікування агентів фінансового сектору. Застосовуючи різні інструменти та канали комунікації, центральний банк намагається контролювати очікування агентів фінансового сектору. Важливість вивчення економічних очікувань полягає в тому, що майбутній вибір та наміри суб'єктів обумовлені їх істотним впливом на поточний вибір, а отже, і на загальний рівень економічної активності. У свою чергу, центральному банку як регулятору грошово-кредитної системи важливо правильно оцінити, що саме буде очікувати аудиторія для отримання позитивного ефекту для економіки в цілому. Найбільшої уваги надається саме інфляційним очікуванням, оскільки вони є одними з головних проблем для економіки багатьох країн та України у тому числі.

Таким чином, очікування є детермінантою фактичного рівня інфляції а отже, відіграють вирішальне значення при аналізі центральним банком поточної ситуації в економіці з тим, щоб спрогнозувати майбутню величину інфляції. Саме цей критерій змушує зробити висновок, про важливість відстежування настроїв економічних агентів при проведенні комунікаційної політики центрального банку. У результаті дослідження можна зробити висновок, що економічні очікування $є$ важливим об’єктом дослідження для центральних банків та саме комунікація може допомогти зробити центральні банки прозорими і тим самим сприяти їх підзвітності та управлінню очікуваннями економічних агентів.

\section{Список використаної літератури:}

1. Evansand G.W. Expectations, Economics of / G.W. Evansand, S.Honkapohja [Електронний ресурс]. - Режим доступу : https://pages.uoregon.edu/gevans/isb304053.pdf.

2. Lucas R.E. Expectations and the Neutrality of Money / R.E. Lucas // Journal of Economic Theory. - 1972. - № 4 (2). pp. 103-124 [Електронний ресурс]. - Режим доступу : http://dx.doi.org/10.1016/0022-0531(72)90142-1.

3. Forsells M. The Rationality of Consumers' Inflation Expectations: Survey Based Evidence for the Euro Area / M.Forsells, G.Kenny // Journal of Business Cycle Measurement and Analysis. - 2004. - P. 13-41 [Електронний pecypc]. - Режим доступу : http://dx.doi.org/10.1787/jbcma-v2004-art3-en.

4. Dias F. Inflation Expectations In the Euro Area: Are the Consumers Rational? Review of World Economics / F.Dias, C.Duarte, A.Rua // Springer. - 2010. - № 146 (3). - Р. 591-607 [Електронний ресурс]. - Режим доступу : http://dx.doi.org/10.1007/ s10290-010-0058-6.

5. Mitchell J. The Rationality and Reliability of Expectations Reported by British Households: Micro Evidence from the British Household Panel Survey / J.Mitchell, M.Weale // Deutsche Bundesbank Discussion Paper Series 1: Economic Studies. - 2007. - № 19.

6. Caroll C.D. Macroeconomic Expectations of Households and Professional Forecasters / C.D. Caroll // Quarterly Journal of Economics. - 2003. - № 118 (1). - P. 269-298 [Електронний ресурс]. - Режим доступу : http://dx.doi. org/10.1162/00335530360535207.

7. Lama M.J. The Role of Media for Consumers' Inflation Expectation Formation / M.J. Lama, S.M. Lein // Journal of Economic Behavior and Organization. - 2014. - № 106. - Р. 62-77 [Електронний ресурс]. - Режим доступу : http://dx.doi. org/10.1016/j.jebo.2014.05.004.

8. Sanusi A.R. Signaling effects of monetary policy in Nigeria: Evidence from the new central bank of Nigeria's communication regime / A.R. Sanusi // Paper presented at the 52nd Annual Conference of the Nigerian Economics Society. - September, 2012.

9. Inflation expectations as a policy tool? / O.Coibion, Y.Gorodnichenko, S.Kumar, M.Pedemonte. - 2018 [Електронний ресурс]. - Режим доступу : https://eml.berkeley.edu/ ygorodni/CGKP.pdf.

10. The Role of Expectations in the FRB/US Macroeconomic Model / F.Brayton, E.Mauskopf, D.Reifschneider and other [Електронний ресурс]. - Режим доступу : https://www.federalreserve.gov/pubs/bulletin/1997/199704lead.pdf.

11. Brubakk L. NEMO - a new macro model for forecasting and monetary policy analysis / L.Brubakk, T.Sveen // Monetary Policy Department, Norges Bank [Електронний ресурс]. - Режим доступу : https://www.norgesbank.no/contentassets/7b0a385f008e421088c70ade4f27a6b6/en/nemo.pdf.

12. Kokonas N. Central Bank Communication and Inflation / N.Kokonas, M.Rousakis. - University of Bath, 2017 [Електронний ресурс]. - Режим доступу : http://www.mwpweb.eu/1/161/resources/research_413_1.pdf.

13. Trust in the Central Bank and Inflation Expectations / D.Christelis, D.Georgarakos, T.Jappelli, M. van Rooij // Amsterdam DNB Working Paper. - 2016. - 496 p.

14. Growth from Knowledge [Електронний ресурс]. - Режим доступу : https://www.gfk.com.

15. Національний банк України [Електронний ресурс]. - Режим доступу : https://bank.gov.ua. 


\section{References:}

1. Evansand, G.W. and Honkapohja, S., Expectations, Economics of, [Online], available at : https://pages.uoregon.edu/gevans/isb304053.pdf

2. Lucas, R.E. (1972), «Expectations and the Neutrality of Money», Journal of Economic Theory, No. 4(2), pp. 103124, [Online], available at: http://dx.doi.org/10.1016/0022-0531(72)90142-1

3. Forsells, M. and Kenny, G. (2004), «The Rationality of Consumers’ Inflation Expectations: Survey Based Evidence for the Euro Area», Journal of Business Cycle Measurement and Analysis, pp. 13-41, [Online], available at: http://dx.doi.org/10.1787/jbcma-v2004-art3-en

4. Dias, F., Duarte, C. and Rua, A. (2010), «Inflation Expectations In the Euro Area: Are the Consumers Rational? Review of World Economics, Springer, No.146 (3), pp. 591-607, [Online], available at: http://dx.doi.org/10.1007/ s10290-010-0058-6

5. Mitchell, J. and Weale, M. (2007), «The Rationality and Reliability of Expectations Reported by British Households: Micro Evidence from the British Household Panel Survey», Deutsche Bundesbank Discussion Paper Series 1: Economic Studies, No. 19.

6. Caroll, C.D. (2003), «Macroeconomic Expectations of Households and Professional Forecasters», Quarterly Journal of Economics, No. 118 (1), pp. 269-298, [Online], available at: http://dx.doi.org/10.1162/00335530360535207

7. Lama, M.J. and Lein, S.M. (2014), «The Role of Media for Consumers' Inflation Expectation Formation», Journal of Economic Behavior and Organization, No. 106, pp. 62-77, [Online], available at: http://dx.doi. org/10.1016/j.jebo.2014.05.004

8. Sanusi, A.R. (2012), «Signaling effects of monetary policy in Nigeria: Evidence from the new central bank of Nigeria's communication regime», Paper presented at the 52nd Annual Conference of the Nigerian Economics Society.

9. Coibion, O., Gorodnichenko Y., Kumar, S. and Pedemonte, M. (2018), Inflation expectations as a policy tool?, [Online], available at: https://eml.berkeley.edu/ ygorodni/CGKP.pdf

10. Brayton, F., Mauskopf, E., Reifschneider, D., Tinsley, P. and Williams, J., The Role of Expectations in the FRB/US Macroeconomic Model, [Online], available at: https://www.federalreserve.gov/pubs/bulletin/1997/199704lead.pdf

11. Brubakk, L. and Sveen, T, «NEMO - a new macro model for forecasting and monetary policy analysis», Monetary Policy Department, Norges Bank, [Online], available at: https://www.norgesbank.no/contentassets/7b0a385f008e421088c70ade4f27a6b6/en/nemo.pdf

12. Kokonas, N. and Rousakis, M. (2017), Central Bank Communication and Inflation, University of Bath, [Online], available at: http://www.mwpweb.eu/1/161/resources/research_413_1.pdf

13. Christelis, D., Georgarakos, D., Jappelli, T. and van Rooij, M. (2016), «Trust in the Central Bank and Inflation Expectations», Amsterdam DNB Working Paper, 496 p.

14. Growth from Knowledge, [Online], available at: https://www.gfk.com

15. National Bank of Ukraine, [Online], available at: https://bank.gov.ua

Буряк Анна Володимирівна - кандидат економічних наук, доцент кафедри фінансів, банківської справи та страхування Сумського державного інституту.

Наукові інтереси:

- поведінкові фінанси, фінанси домогосподарств;

- банківський нагляд та регулювання;

- суспільна довіра до фінансового сектору країни.

ORCID.org/ 0000-0003-2954-483X

E-mail: a.buriak@uabs.sumdu.edu.ua

Кривич Яна Миколаївна - кандидат економічних наук, доцент кафедри фінансів, банківської справи та страхування Сумського державного інституту.

Наукові інтереси:

- анківська справа;

- поведінка агентів фінансового сектору;

- відновлення суспільної довіри до фінансового сектору країни.

ORCID.org/0000-0002-3401-0878

E-mail: y.kryvych@uabs.sumdu.edu.ua

Сердюк Катерина Вікторівна - магістр першого курсу кафедри фінансів, банківської справи та страхування Сумського державного інституту.

Наукові інтереси:

- політика центрального банку;

- економічні очікування агентів фінансового сектору.

- довіра до центрального банку.

ORCID.org/ 0000-0002-6348-2014

E-mail: katerynaserduck@gmail.com 